\title{
COX-2 テクノロジーの革新
}

\section{Carlo Patrono}

Jpn. J. Clin. Immun., 23 (6) : 683 685, 2000.

\section{Innovation in COX-2 Technology}

\section{Universita di Chieti “G.D' Annunzio" Chieti, Italy}

非ステロイド性抗炎症薬はWHOにより NSAIDs と名づけられている. NSAIDsには aspirin 第 1 世 代としていくつかのグループがあるが, COX-2 選択 的阻害薬である celecoxib および rofecoxib は第 4 世 代に属すると考元られる（図 1).

それぞれの NSAIDsの生化学的特徴を考えていく うえで, aspirinのたどってきた道を振り返ることは 重要である.とくに約 25 年前にその作用メカニズム

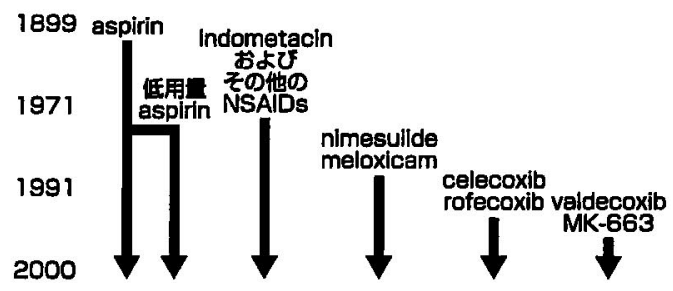

図 1 COX-2 阻害薬開発の歴史

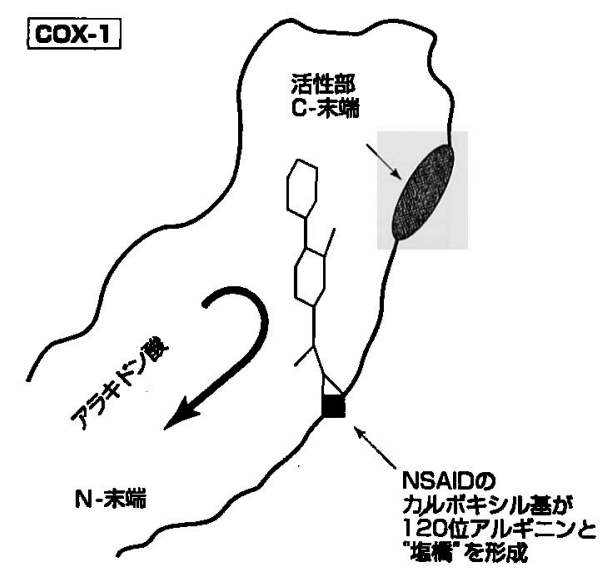

が明らかにされ，低用量では血小板 COX-1 の特異的 阻害薬となることが判明したのちの経緯は重要であ る. 選択的 $\operatorname{COX}$ 阻害薬の臨床的意義に関して, aspirinから重要な教訓を学ふことができよう。

\section{I . aspirin に学む引 COX-2 阻害薬の意義}

プロスタグランジン H合成酵素はシクロオキシゲナ 一ゼとも呼ばれる膜結合蛋白である。その立体構造の 一部にいわゆるシクロオキシゲナーゼチャネルがあ る.このチャネルの中に aspirin は入りこみ（図2）， すべての非ステロイド性抗炎症薬に共通のドッキング サイトArg 120 に招さまる。この位置から aspirin は 選択的に 530 番目のセリンをアセチル化し，このチャ ネルのもっとも狭い部分を占拠する．このためシクロ オキシゲナーゼチャネルは閉鎖され，この酵素の活性 化が妨げられる.こうして aspirin 服用約 1 時間後に

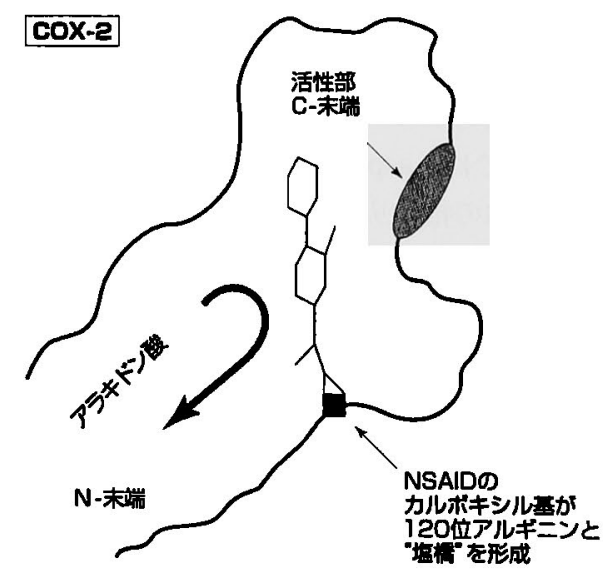

図 2 従来の NSAIDs の COX- 1 および COX-2 への結合部位 
は血小板のトロンボキサン A 2 阻害作用は最大とな る。

血栓溶解作用の臨床的効用も知られている。急性心 筋梗塞患者に発症後 24 時間以内に aspirin $160 \mathrm{mg}$ を 投与すると 5 週間後までの死亡率はプラセボ群よりも 明らかに減ることが示されている，このような aspirinの作用からみると，望ましい抗血小板効果を得る ための臨床薬理学的評価は, ex vivo で全血中のトロ ンボキサンA 2 の産生量を測定すればよいかもしれ ない.

実際には, aspirin の心血管障害予防効果は心血管 系のリスク因子をどれだけ持っているかによって異な る.したがって Physician's Health Study の対象者 のように，心血管系のリスクが少ない場合は aspirin はあまりメリットはないが，不安定狭心症のように八 イリスク患者ではメリットは大きい.そこで，aspirin を投与するなら, 出血のリスクと心血管系のリス クをはかりにかける必要がある.

aspirin による出血のリスクは 1000 人・年あたり1 〜2人である. asprinによる消化管出血は COX-1 依 存性であり，1つは血小板，もう1つは消化管の粘膜 によって左右される，血小板に関していえば，aspirin $30 \mathrm{mg} /$ 日を越えればいかなる投与量でも用量非依 存性となる。すでに $30 \mathrm{mg} /$ 日で血小板のトロンボキ サン A 2 産生阻害効果は最大になるからである. 第 2 の消化管粘膜に関していえば，こちらは用量依存性で あり, 消化管粘膜でのプロスタグランジンとくに細胞 保護作用があるプロスタグランジン E 2 合成阻止作用 に関連している。そして，比較的新しい粘膜病変部が あるとハイリスクである.

Garcia Rodriguez らは抗血小板薬として aspirin を投与した場合と ticlopidinのようなシクロオキシゲ ナーゼ阻害作用のない抗血小板薬を投与した場合の上 部消化管出血の相対リスクを多数例を対象に調査して いる. その成績では, aspirin, 他の抗血小板薬とも に上部消化管出血の相対リスクは非投与群の 2 倍以上 で，各楽㓣間にはそれほど差はなかった，aspirin以 外の NSAIDs の上部消化管出血の相対りスクは, 低 用量では 2〜3 倍, 高用量では 5〜6 倍となる.

さらに彼らは消化管疾患の既往と上部消化管出血の 頻度について調査している．潰場合併の既往がある場 合は，相対リスクは10〜12 倍と高くなり，これに NSAIDsを用いると約 25 倍と，一段と高くなること が明らかにされている.

\section{II. ex vivo での $\mathrm{COX}-1 \cdot \mathrm{COX}-2$ 阻害活性の測定}

このような事実から，消化管出血を防ぐには，血小 板および消化管粘膜の COX-1 の活性を保つという戦 略が浮かび上がってくる，COX-2 の選択的阻害は八 イリスク群には望ましい戦略となろう。

我々の研究室では，ヒト全血を用いて，血小板の COX-1 と箪球の COX-2 の活性を測定する方法を開発 した。それぞれの活性を $50 \%$ 阻止する濃度を IC 50 とし, タテ軸に COX-2 の IC 50 を, ヨコ軸に COX-1 のIC 50 をとり,タテ軸ヨコ軸に対して 45 度の線を 引くと,この線はちょうど COX-1 と COX-2 阻害作 用が等しいことを示す，各薬犁をこの座標にプロット してみると, indometacin, ibuprofen, naproxan, nabumetone の活性代謝物である6-MNA は，ほほ この 45 度の線上に並ふ。. 選択的 COX-2 阻害薬は 45 度の線よりも右に位置し，COX-1 を阻害しようと考 えれば，より高濃度を用いなければならなくなる。そ して, 薬剤がこの 45 度の線から離れれば離れるほど, 選択性はより高いことになる。

diclofenacや meloxicam はこの線よりも右にあ り, COX-2 選択性は COX-1 に比べて 10〜20倍も強 い.しかし，このような in vitroでの選択性が，その
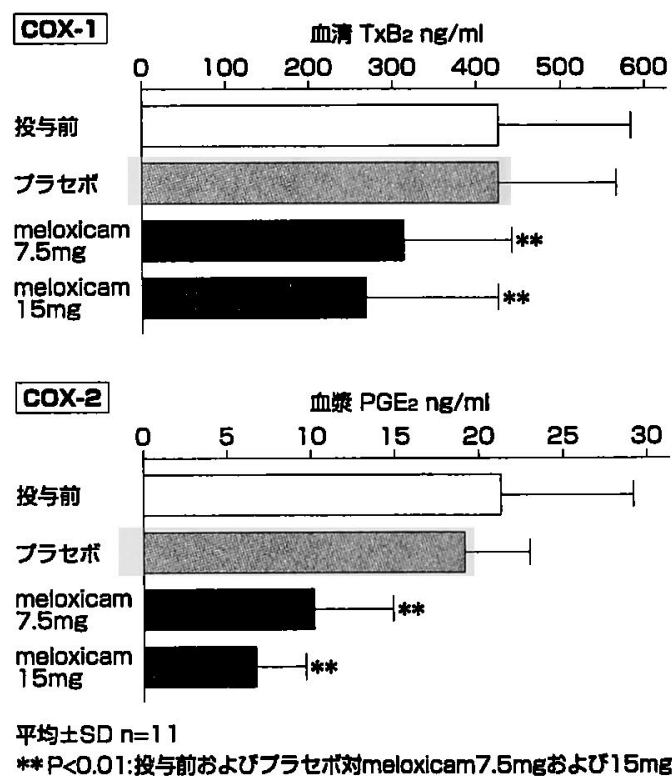

図 3 meloxicam 反復投与 $(7.5 \mathrm{mg} /$ 日および 15 $\mathrm{mg} /$ 日, 7 日間)が COXに及ほす影響一 ex vivo での COX アイソザイム活性 
まま in vivoにあてはめることができるかどうかは疑 問である.

そこで, 我々は meloxicam $(7.5 \mathrm{mg}$ お よひ 15 mg）とプラセボを用いて健常人ボランティア11名を 対象に無作為比較試験を行った.

血小板の COX-1 活性はトロンボキサン B 2 を測定 し評価した，単球の COX-2 活性はプロスタグランジ ンE 2 を测定し評価した. meloxicam は用量依存性 に COX-1 および COX-2 を阻害した。 in vivoで予想 された COX-2 阻害活性よりもさらに強い抑制作用が 認められた。それでも血小板の COX-1 阻害活性はプ ラセボ群に比べると有意に強かった（図 3）. meloxicam の血中濃度とCOX-1 および COX-2 の\%阻害活 性を個々の対象例ごとにプロットしてみると, 血中濃 度, $\operatorname{COX}$ 阻害活性ともに, 著しい個人差が認められ た. COX-2に関しては0〜85\%, COX-1に関しては

1) Brooks, P., et al.: Interpreting the clinical significance of the differential inhibition of cyclooxygenase- 1 and cyclooxygenase-, 2 : Rheumatology, $38: 779 \sim 788,1999$.

2) Panara, M.R., et al. : Dose-dependent inhibition of platelet cyclooxygenase-1 and monocyte cyclooxygenase-2 by meloxicam in healthy subjects. J. Pharmacol. Exp. Ther., $290: 276 \sim 280,1999$.

3) Patrono, C., et al. : Platelet-active drugs: the relationships among dose, effectiveness, and
0〜75\% と大きくバラついていた。

したがって, 重篤な消化管出血は単に COX-2 選択 性だけではなくて, さまざまな要因から生じる点に留 意する必要がある，患者の薬郕に対する反応性や薬物 動態の違い, 消化管疾患の既往などのリスク因子に加 えて, 薬郕がもっている薬物動態学的特徵, $\mathrm{COX}-2$ 選択性など，さまざまな因子が関与している。

これは rofecoxibでも同様で，RA 患者に投与した ところ, COX-2 に関しては 80〜 $100 \%, \mathrm{COX}-1$ に関 しては 0 20\%の阻害活性が認められた. celecoxib に関しても同様な成績が得られている。これらの楽剤 は消化管粘膜だけでなく，腎尿細管機能，血管内皮細 胞機能にも影響を及ぼすことが知られている. COX は痛みや炎症ばかりでなく，さまざまな病態に関わっ ている点にも注意を向ける必要がある。

献

side effects. Chest., $114: 470 \mathrm{~S} \sim 488 \mathrm{~S}, 1998$.

4) Patrono, C.: Prevention of myocarrdial infarction and stroke by aspirin-different mechanism?: Thromb Res., 92: S 7 S 12, 1998.

5) Rodoriguez, G., et al. : Differential effects of aspirin and non-aspirin nonsteroidal antiinflamatory drugs in the primary prevention of myocardial infarction in postmenopausal woman. Epidemiology, $11: 382 \sim 387,2000$. 